\title{
Nutrient Enrichment Bioassay: A Study with Indigenous Phytoplankton of a Lagoon Receiving Sugar Mills Effluents
}

\author{
Taofikat Abosede Adesalu (Corresponding author) \\ Department of Botany, University of Lagos, Nigeria
}

Tel: 234-802-312-7185Ｅ-mail: boseadesalu@yahoo.com

Maria Abimbola Akindele

Department of Botany, University of Lagos, Nigeria

Received: September 5, 2013 Accepted: September 25, 2013 Published: October 28, 2013

doi:10.5296/jee.v4i2.4238

URL: http://dx.doi.org/10.5296/jee.v4i2.4238

\begin{abstract}
The response of indigenous phytoplankton population to nutrients enrichment bioassay of phosphate-phosphorus and nitrate-nitrogen of different concentrations were studied for three locations created as "before the effluents discharge; point of effluents discharge and after the effluents discharge. For the present study, physico-chemical properties of sugar milling effluents recorded $1.50 \mathrm{mg} / \mathrm{L}$ of dissolved oxygen concentration; biological oxygen demand value was $150 \mathrm{mg} / \mathrm{L}$ while chemical oxygen demand recorded $59.0 \mathrm{mg} / \mathrm{L}$ with the $\mathrm{pH}$ of 4.82 . Four divisions, Bacillariophyta, Cyanophyta, Chlorophyta and Euglenophyta were predominantly recorded for the combinations while the optimal growth was recorded for all the stations at $100^{\mathrm{P}} / 50^{\mathrm{N}}$ nutrients combination.
\end{abstract}

Keywords: Nutrients, Bioassay, Phytoplankton, Effluents 


\section{Introduction}

Phytoplankton constitute the bedrock or basis of grazing food chain and food web in surface water systems, they are recognized worldwide as bioindicator organisms in the aquatic environment (Yakubu et al., 2000). Aquatic organisms have been used in comparative monitoring of pollution effects in different systems and to locate sources of toxicants (Philips 1989). According to Birge et al., (1989) biomonitoring approach has proved to be promising as a reliable means of quantifying biological effects of complex effluents, although a large number of aquatic organisms have been used for assessment, some workers have recognized the importance of algae as indicator in assessment and evaluation of pollution (Prasad and Manjula, 1980; Nandan and Patel, 1986; Javed and Hayat, 1996).

In Nigeria, numerous workers have also shown that phytoplankton composition and population density are suitable to draw conclusions on the conditions present in the aquatic body. (Adesalu, 2007, Adesalu et al 2008; Kadiri and Azomani 1993; Nwankwo and Akinsoji, 1992). Aquatic ecosystems are affected by several health stressors that significantly deplete biodiversity. In the future, the loss of biodiversity and its effect are predicted to be greater for aquatic ecosystems than for terrestrial ecosystems (Sala et al., 2000). The major known sources of water pollution are municipal, industrial and agricultural while the most polluting of them are sewage and industrial waste discharges into rivers. Alam et al., (2007) reported that industrial effluents contain heavy metals, acid, hydrocarbon and atmospheric decomposition and the aquatic environment is becoming polluted not only because of a single source but a variety of sources include domestic and industrial wastes. As today's technology progresses, the natural environment suffers from the detrimental effects of pollution, the growth of human population and rapid industrialization led to increasing use of urban waters as sewers, compromising their other uses.

The discharge of industrial effluents has led inevitably, to alterations in the quality and ecology of receiving water bodies thus brings new challenges to both water resource managers and aquatic ecologists. Highly coloured water, besides being aesthetically unpleasing, limits light penetration, reducing production of phytoplankton and by association, zooplankton, fish and dissolved oxygen supply. Effluents with a high temperature can be of concern because high temperatures deplete dissolved oxygen levels in the water body and in general, sugar mill effluents contain acidic and alkaline compounds, a significant concentration of suspended solids, high Biological and Chemical Oxygen demand.

The significance of measuring algal growth potential in water samples is that differentiation can be made between the nutrients of a sample determined by chemical analysis and the nutrients that are actually available for algal growth. The addition of nutrients (usually nitrogen and phosphorus singly or in combination) to the sample can give an indication of which nutrients are limiting for algal growth ( Kadiri and Azomani, 1993; Miller et al., 1974; Greene et al., 1975,1976, 1978; Payne, 1976; Gerhold, 1976). The objectives of algal growth potential tests might include the establishment of baseline data, determination of the growth controlling nutrients, the presence of a toxicant, the influence of an added nutrients or the source of a nutrient or toxicant when several inflows are involved. 
A certain degree of variability can be expected with any assay or survey; once the baseline data are established, changes can be measured. Sustainability of lagoon fisheries is now threatened by coastal degradation for the great majority of species which spend their earliest stages near coast, estuarine, brackish or freshwater. The most noticeable hydrological features of lagoons and estuaries ecosystem in Nigeria is the diurnal and seasonal variations in salinity level of the water usually caused by tidal effects and influx of inshore waters (Ibe, 1988). In terms of biological production, the Nigeria lagoons have wide diversity of both flora and fauna (Amadi, 1990). Dublin-Green and Tobor (1992) classified the resources in the marine environment into two: renewable and non-renewable. They include the algae, some plants and finfish, marine mammals, reptiles and shell fishes.

About $80-85 \%$ of the industries in Nigeria are located in Lagos State and they all probably discharge their effluents into the Lagos lagoon complex. The effluents discharged are mainly untreated, while very few industries have any treatment plants. The proliferation of urban and industrial establishments along the shores of the lagoon has resulted in a complex mix of both domestic and industrial wastes.

\section{Materials and Methods}

\subsection{Study Area}

The study was carried out on the Liverpool creek around a point that receives effluents discharged from Sugar mill refineries located at Wharf Road Tincan Island Apapa, Lagos State. The company is responsible for the milling and production of sugar, the effluents of which are conveyed through an underground tunnel into Liverpool creek connecting to the Badagry creek and deposited into the Lagos lagoon. Lagos lagoon is one of the major Lagoonal systems in Nigeria, its an extremely important ecosystem and apart from high levels of biological productivity, it plays various important ecological roles such as transportation of nutrients and organic material to marine system through circulation. The Lagos lagoon is more than $50 \mathrm{~km}$ long and 3 to $13 \mathrm{~km}$ wide, separated from the Atlantic Ocean by long sand spit 2 to $5 \mathrm{~km}$ wide, which has swampy margins on the lagoon side. Its surface area is approximately $6,354.7 \mathrm{~km}^{2}$. There were no vegetations present around the study site, except for site of refuse dump and stream bathing.

\subsection{Collection of Water Samples}

The methods described by Kadiri and Azomani (1993) were used for this experiment. In addition, the effluents were also collected directly from the tunnel before getting into the lagoon and analysed for physico-chemical parameters. Water samples were collected from three points "before effluents discharge", (N $06^{0} 26^{\prime} 03.9$ ", E $003^{0} 21$ ' 44.9)", "at the point of effluents discharge", (N06 $26^{\circ}$ 06.2", E $003^{0} 21^{\prime}$ "42.5")" and "after the point of effluents discharge" (N $06^{0} 26^{\prime} 0.94 "$, E $\left.003^{0} 21^{\prime} 40.2^{\prime \prime}\right)$, using Global positioning system. The samples were filtered using $100 \mu \mathrm{m}$ plankton net to eliminate the presence of zooplankton and other objects. 


\subsection{Laboratory Analysis}

In the laboratory, twenty-one uniform size conical flasks of $100 \mathrm{ml}$ capacity were used for the experiment. Into each conical flask, $50 \mathrm{ml}$ of the water samples were measured and spiked with phosphate and nitrate in the following combinations. The concentrations of the salts used were measured using AdventureTM Ohaus weighing balance:

$\begin{array}{ccc}\mathrm{PO}_{4}\left(\mu \mathrm{gl}^{-1}\right) & & \mathrm{NO}_{3}\left(\mu \mathrm{gl}^{-1}\right) \\ 0 & + & 0 \\ 100 & + & 0 \\ 100 & + & 50 \\ 100 & + & 200 \\ 25 & + & 50 \\ 50 & + & 50 \\ 0 & + & 200\end{array}$

The experiment was set up in triplicate for the three sampling sites. The flasks content were thoroughly mixed and arranged near a north-facing window where they received light intensity from the day light and aeration. All the cultures were maintained at room temperature of $26 \pm 2^{0} \mathrm{C}$ and continuous light intensity from a fluorescent tube of $40 \mathrm{watts}$. The flasks were shaken manually daily to prevent clumping of phytoplankton cells. Growth of phytoplankton was measured as optical density at $680 \mathrm{~nm}$ using the spectrophotometer machine CE2041 at two days intervals for a period of 14 days. Microscopic examination of the treatments was carried out using Olympus XSZ-N107 binocular microscope at the end of the experiment to determine which phytoplankton grew. Adesalu (2007), Olaniyan (1975), Whitford and Schumacher (1973), Wimpenny (1966), were adequately consulted to confirm identification.

\subsection{Physico-Chemical Analysis}

\subsubsection{Surface Water}

The surface water temperature was measured using mercury-in-glass thermometer while transparency was determined with a Secchi disc and salinity was determined using a hand refractometer.

\subsubsection{Analysis of Effluents}

Total suspended solid and total dissolved solids were determined using the gravimetric method (APHA 1998). Total hardness was determined by EDTA titrimetric method, chloride using the argentometric method and conductivity of the effluents sample using a conductivity meter JENWAY (4071). The hydrogen ion concentration of the sample was obtained using a Cole Palmer Test 3 meter while alkalinity was measured by titration method. Dissolved Oxygen was determined using the titrimetric method; while Biological oxygen demand was done after the dissolved oxygen had been measured using the standard method of biochemical consumption of oxygen in 5 days at $20^{\circ} \mathrm{C}$. With the use of closed reflux method Chemical Oxygen Demand was determined. The cations Calcium, Sodium, Magnesium and 
Potassium were determined using the EDTA titrimetric method (APHA 1998). Atomic absorption spectrophotometer was used for the determination of heavy metals.

\subsubsection{Nutrients Determination}

Hach Cadmium reduction method was used for nitrate determination, (APHA 1998). Phosphate-phosphorus is known to be important in a number of ways, one being that it facilitates the uptake of nitrogen. It was determined by ascorbic acid method while gravimetric method was used to measure the sulphate, Oil and grease was determined using the carbon tetrachloride method and filtrate viewed at $450 \mathrm{~nm}$ with a DR2000 spectrophotometer and the values obtained were recorded in milligrams per litre $\left(\mathrm{mgL}^{-1}\right)$, (APHA 1998).

\section{Results}

\subsection{Physico-Chemical Parameters}

The surface water temperature at the three points of the study (before effluents, point of effluents and after effluents discharge) had a constant value of $32^{\circ} \mathrm{C}$ while the transparency for before the point of effluents was $9 \mathrm{~cm}$; point of effluents recorded the lowest value $(5 \mathrm{~cm})$ and after the point of effluents had $29 \mathrm{~cm}$. The salinity values recorded $0.10 \%, 0.19 \%$ and $0.20 \%$ for point of effluents, after effluents and before effluents respectively.

\subsection{Effluents}

The total suspended solid value was $130.0 \mathrm{mg} / \mathrm{L}$ while total dissolved solids of the effluents had $496.0 \mathrm{mg} / \mathrm{L}$. The total hardness value recorded $988.0 \mathrm{mg} / \mathrm{L}$ while the chlorine content and conductivity values were $60.0 \mathrm{mg} / \mathrm{L}$ and $1780 \mu \mathrm{S} / \mathrm{cm}$ respectively and hydrogen ion concentration of the effluents was $4.82 \mathrm{mg} / \mathrm{L}$. Dissolved oxygen measured was $1.50 \mathrm{mg} / \mathrm{L}$ and the effluents discharge had high biological oxygen demand value of $150.0 \mathrm{mg} / \mathrm{L}$. Chemical oxygen demand recorded $59.0 \mathrm{mg} / \mathrm{L}$ and the high content of Calcium and Magnesium $(164.0 \mathrm{mg} / \mathrm{L}$ and $824 \mathrm{mg} / \mathrm{L})$ were recorded respectively while Sodium ion recorded $23.59 \mathrm{mg} / \mathrm{L}$ and Potassium ions measured was $10.50 \mathrm{mg} / \mathrm{L}$. The nutrients values of $3.20 \mathrm{mg} / \mathrm{L}$ and $0.78 \mathrm{mg} / \mathrm{L}$ were recorded for nitrate-nitrogen and phosphate-phosphorus respectively. Sulphate recorded same value $(0.78 \mathrm{mg} / \mathrm{L})$ as phosphate-phosphorus while oil and grease value was $132.0 \mathrm{mg} / \mathrm{L}$ neither Cadmium $(\mathrm{Cd})$ nor Lead $(\mathrm{Pb})$ was present ((Table 1).

Table 1. Results of physico-chemical parameters of Sugar mill effluents.

\begin{tabular}{|l|l|}
\hline Parameters & $\begin{array}{l}\text { Results obtained } \\
(\mathrm{mg} / \mathrm{L})\end{array}$ \\
\hline Total Suspended Solid & 130.0 \\
\hline Total Dissolved Solid & 496.0 \\
\hline Alkalinity & ND \\
\hline Total Hardness & 988.0 \\
\hline Sulphate & 0.78 \\
\hline Nitrate-nitrogen & 3.20 \\
\hline Phosphate-phosphorus & 0.78 \\
\hline
\end{tabular}




\begin{tabular}{|l|l|}
\hline Chlorine & 60.0 \\
\hline Calcium & 164.0 \\
\hline Magnesium & 824.0 \\
\hline Sodium & 23.59 \\
\hline Potassium & 10.50 \\
\hline Cadmium & ND \\
\hline Lead & ND \\
\hline Biological Oxygen Demand & 150.0 \\
\hline Chemical Oxygen Demand & 59.0 \\
\hline Dissolved Oxygen & 1.50 \\
\hline $\begin{array}{l}\text { Hydrogen ion Concentration } \\
(\mathrm{pH})\end{array}$ & 4.82 \\
\hline Oil and Grease & 132.0 \\
\hline
\end{tabular}

\subsection{Biological Analysis}

\subsubsection{Phytoplankton}

The list of the phytoplankton identified for the bioassay study is presented on Table 2 . Oscillatoria spp., Navicula sp. and Nitzchia sp. were fairly populated at the point of the sugarmill's effluents discharge. Comparing the nutrients concentrations of $100^{\mathrm{P}} / 50^{\mathrm{N}}$ and $0^{\mathrm{P}} / 200^{\mathrm{N}}$, it was observed that $0^{\mathrm{P}} / 200^{\mathrm{N}}$ combination recorded the highest number of organisms population $(\leq 100.3)$ for after point of effluents followed by before point of effluents $(\leq 99.6)$ while the point of effluents discharge recorded $(\leq 71.2)$ population showing phosphate-phosphorus as the limiting factor (Fig.1). However, the combination $100^{\mathrm{P}} / 50^{\mathrm{N}}$ recorded an increase in population $(\leq 88)$ for the point of effluents, decrease $(\leq 100.1)$ for after point of effluents discharge and the same value $(\leq 99.1)$ for before the point of effluents (Fig.2). It was observed that growth dropped at day 8 and later start increasing in most nutrients combinations for before effluents point (Figs 3) while point of effluents and after effluents point followed almost same pattern in which growth increases from day 2 to 8 after which it started declining (Figs 4 and 5) respectively. Highest value of population growth for the entire study was recorded at $50^{\mathrm{P}} / 50^{\mathrm{N}}$ (Fig.6). The combinations $25^{\mathrm{P}} / 50^{\mathrm{N}}$ and $50^{\mathrm{P}} / 50^{\mathrm{N}}$ followed almost same pattern with the lowest values recorded for the point of effluents discharge (Figs $6 \mathrm{a}$ and $6 \mathrm{~b}$ ) while $100^{\mathrm{P}} / 0^{\mathrm{N}}$ combinations indicated the importance of phosphate-phosphorus over nitrate-nitrogen in aquatic environment (Fig.7). 


\section{Macrothink}

Table 2. Phytoplankton identified at the Liverpool part of Lagos lagoon after nutrient enrichment bioassay.

\begin{tabular}{|c|c|c|c|}
\hline Treatments & Before effluents & Point of effluents & After effluents \\
\hline $0 \mathrm{PO}_{4}+0 \mathrm{NO}_{3}$ & $\begin{array}{l}\text { Amphiphora sp. } \\
\text { Nitzschia } \mathrm{sp} . \\
\text { Oscillatoria bonnetti kutz } \\
\text { Oscillatoria formosa } \\
\text { Oscillatoria limosa (C.A. } \\
\text { Agardh) } \\
\text { Pinnularia } \mathrm{sp} .\end{array}$ & $\begin{array}{l}\text { Oscillatoria limosa } \\
\text { Pinnularia } \mathrm{sp} . \\
\text { Cyclotella } \mathrm{sp} . \\
\text { Euglena } \mathrm{sp} .\end{array}$ & $\begin{array}{l}\text { Amphiphora sp. } \\
\text { Cyclotella } \mathrm{sp} . \\
\text { Surirella } \mathrm{sp} . \\
\text { Tabellaria sp. } \\
\text { Pinnularia sp. } \\
\text { Cosmarium sp. }\end{array}$ \\
\hline $100 \mathrm{PO}_{4}+0 \mathrm{NO}_{3}$ & $\begin{array}{l}\text { Amphiphora sp. } \\
\text { Gyrosigma scalproides } \\
\text { Navicula } \mathrm{sp} . \\
\text { Oscillatoria bonnetti kutz } \\
\text { Pinnularia } \mathrm{sp} .\end{array}$ & $\begin{array}{l}\text { Cyclotella sp. } \\
\text { Lyngbya sp. } \\
\text { Tabellaria sp. }\end{array}$ & $\begin{array}{l}\text { Amphicora } \mathrm{sp} . \\
\text { Cymbella } \mathrm{sp} . \\
\text { Euglena spiroides } \\
\text { G. scalpoides } \\
\text { Spirulina } \mathrm{sp}\end{array}$ \\
\hline $100 \mathrm{PO}_{4}+50 \mathrm{NO}_{3}$ & $\begin{array}{l}\text { Amphiphora } \mathrm{sp} . \\
\text { Coscinodiscus } \mathrm{sp} . \\
\text { Navicula } \mathrm{sp} . \\
\text { Nitzschia } \mathrm{sp} . \\
\text { Oscillatoria formosa } \\
\text { Oscillatoria limosa (C.A. } \\
\text { Agardh) } \\
\text { Spirulina } \mathrm{sp} .\end{array}$ & $\begin{array}{l}\text { Coscinodiscus } \mathrm{sp} . \\
\text { Euglena } \mathrm{sp} . \\
\text { Navicula } \mathrm{sp} . \\
\text { Spirulina } \mathrm{sp} .\end{array}$ & $\begin{array}{l}\text { Amphiphora } \mathrm{sp} . \\
\text { Navicula } \mathrm{sp} . \\
\text { Nitzschia } \\
\text { sigmoidea } \\
\text { Oscillatoria } \\
\text { limosa } \\
\text { Synedra } \mathrm{sp} . \\
\text { Volvox } \mathrm{sp} .\end{array}$ \\
\hline $100 \mathrm{PO}_{4}+200 \mathrm{NO}_{3}$ & $\begin{array}{l}\text { Amphiphora } \mathrm{sp} . \\
\text { Coscinodiscus } \mathrm{sp} . \\
\text { Cyclotella } \mathrm{sp} . \\
\text { Navicula } \mathrm{sp} . \\
\text { Oscillatoria } \mathrm{sp} .\end{array}$ & $\begin{array}{l}\text { Chlamydomonas } \\
\text { sp. } \\
\text { Cosmarium sp. } \\
\text { Navicula } \mathrm{sp} . \\
\text { Pinnularia } \mathrm{sp} . \\
\text { Nitzschia thermalis }\end{array}$ & $\begin{array}{l}\text { Amphicora sp } \\
\text { Navicula } \mathrm{sp} . \\
\text { Nitzschia } \\
\text { sigmoidea } \\
\text { Oscillatoria sp. } \\
\text { Pinnularia } \mathrm{sp.} \\
\end{array}$ \\
\hline $25 \mathrm{PO}_{4}+50 \mathrm{NO}_{3}$ & $\begin{array}{l}\text { Amphiphora sp. } \\
\text { Coscinodiscus lineatus } \text { Ehr } \\
\text { Navicula } \text { sp. } \\
\text { Nitzschia } \text { sp. } \\
\text { Oscillatoria } \text { sp. }\end{array}$ & $\begin{array}{l}\text { Chlamydomonas } \\
\text { sp. } \\
\text { Cyclotella sp. } \\
\text { Navicula } \mathrm{sp} . \\
\text { Oscillatoria } \mathrm{sp} . \\
\text { Spirulina } \mathrm{sp} .\end{array}$ & $\begin{array}{l}\text { Amphiphora sp. } \\
\text { Cymbella } \mathrm{sp.} \\
\text { Cyclotella } \mathrm{sp.} \\
\text { Euglena sp. } \\
\text { Oscillatoria } \\
\text { formosa } \\
\text { Oscillatoria } \\
\text { limosa (C.A. } \\
\text { Agardh) }\end{array}$ \\
\hline $50 \mathrm{PO}_{4}+50 \mathrm{NO}_{3}$ & $\begin{array}{l}\text { Amphiphora sp. } \\
\text { Euglena sp. }\end{array}$ & $\begin{array}{l}\text { Chlamydomonas } \\
\text { sp. }\end{array}$ & $\begin{array}{l}\text { Amphiphora sp. } \\
\text { Cyclotella sp. }\end{array}$ \\
\hline
\end{tabular}




\begin{tabular}{|c|c|c|c|}
\hline & $\begin{array}{l}\text { Oscillatoria bonnetti } \\
\text { Navicula } \mathrm{sp} . \\
\text { Nitzschia } \mathrm{sp} . \\
\text { Pinnularia sp. }\end{array}$ & $\begin{array}{l}\text { Cosmarium sp } \\
\text { Euglena sp. }\end{array}$ & $\begin{array}{l}\text { Microcystis sp. } \\
\text { Navicula } \mathrm{sp} . \\
\text { Nitzschia } \mathrm{sp} . \\
\text { Pinnularia } \mathrm{sp} . \\
\text { Synedra } \mathrm{sp} . \\
\text { Microcystis sp. }\end{array}$ \\
\hline $0 \mathrm{PO}_{4}+200 \mathrm{NO}_{3}$ & $\begin{array}{l}\text { Amphiphora sp. } \\
\text { Cyclotella meneghiniana } \\
\text { Kutz } \\
\text { Navicula sp. } \\
\text { Oscillatoria bonnetti kutz } \\
\text { Oscillatoria formosa } \\
\text { Oscillatoria limosa (C.A. } \\
\text { Agardh) } \\
\text { Pinnularia sp. }\end{array}$ & $\begin{array}{l}\text { Chlamydomonas } \\
\text { sp. } \\
\text { Cosmarium sp. } \\
\text { Cyclotella } \mathrm{sp.} \\
\text { Navicula } \mathrm{sp.} \\
\text { Pinnularia } \mathrm{sp} .\end{array}$ & $\begin{array}{l}\text { Amphiphora sp. } \\
\text { Cymbella } \mathrm{sp} . \\
\text { G. scalpoides } \\
\text { Spirulina } \mathrm{sp} . \\
\text { Tabellaria } \mathrm{sp} . \\
\text { Nitzschia } \mathrm{sp} . \\
\text { Navicula } \mathrm{sp} . \\
\text { Aulacoseira } \mathrm{sp} . \\
\text { Synedra } \mathrm{sp} . \\
\text { Microcystis } \mathrm{sp} .\end{array}$ \\
\hline
\end{tabular}

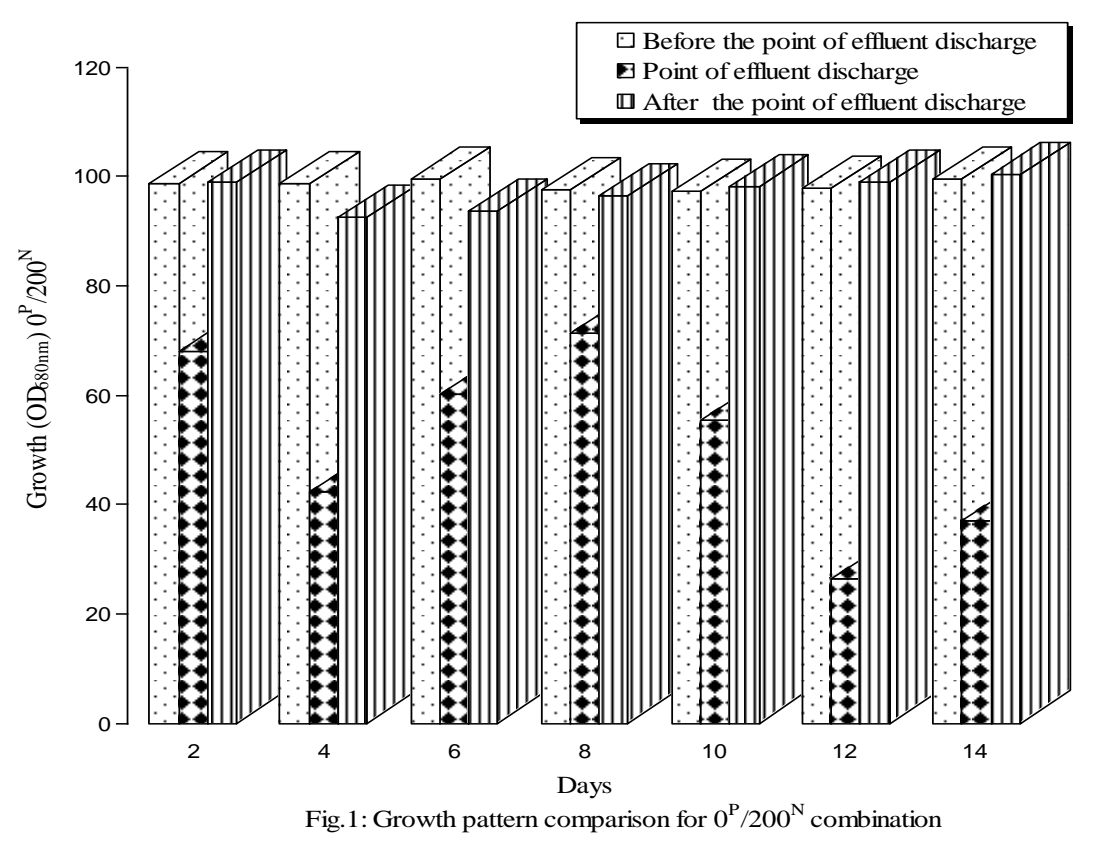




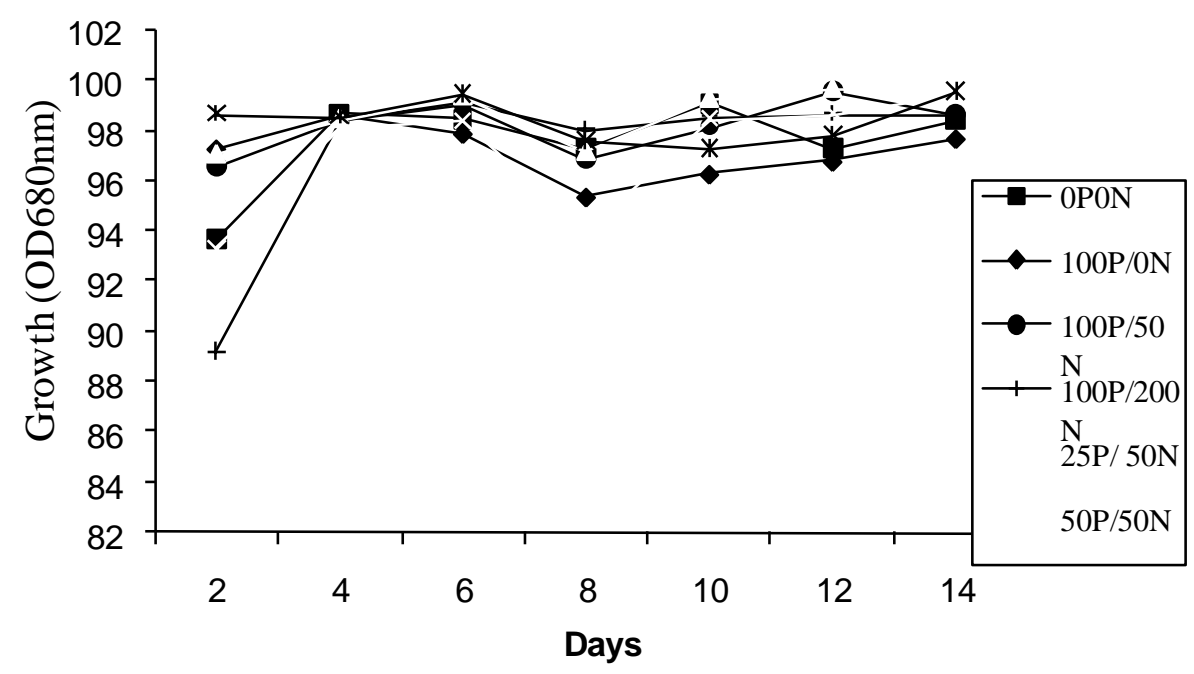

Fig.3: Growth response at "Before effluents discharge point" for all combinations.

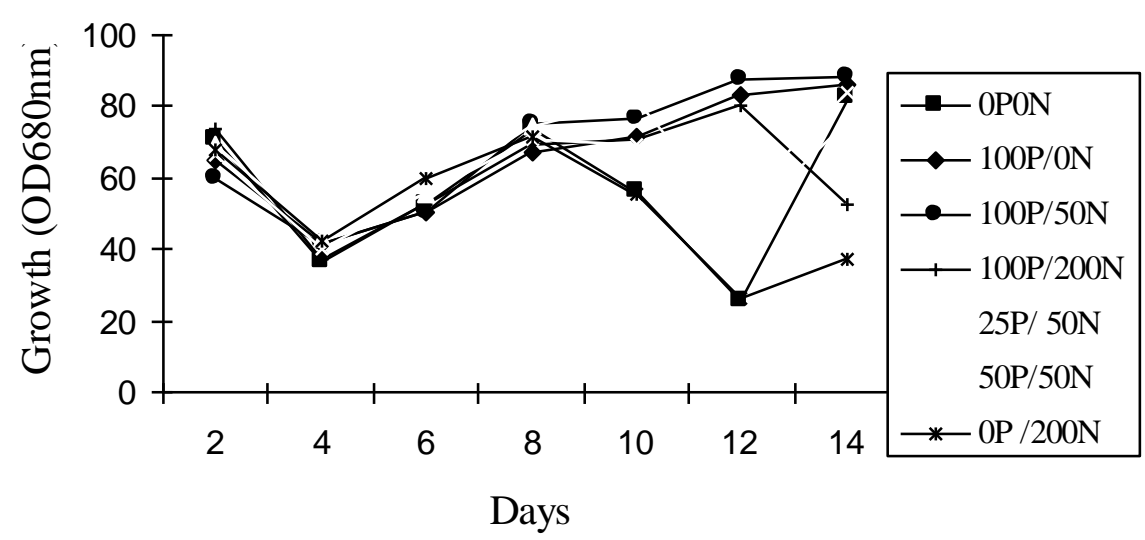

Fig. 4: Growth response at "Point of effluents discharge" for all combinations. 


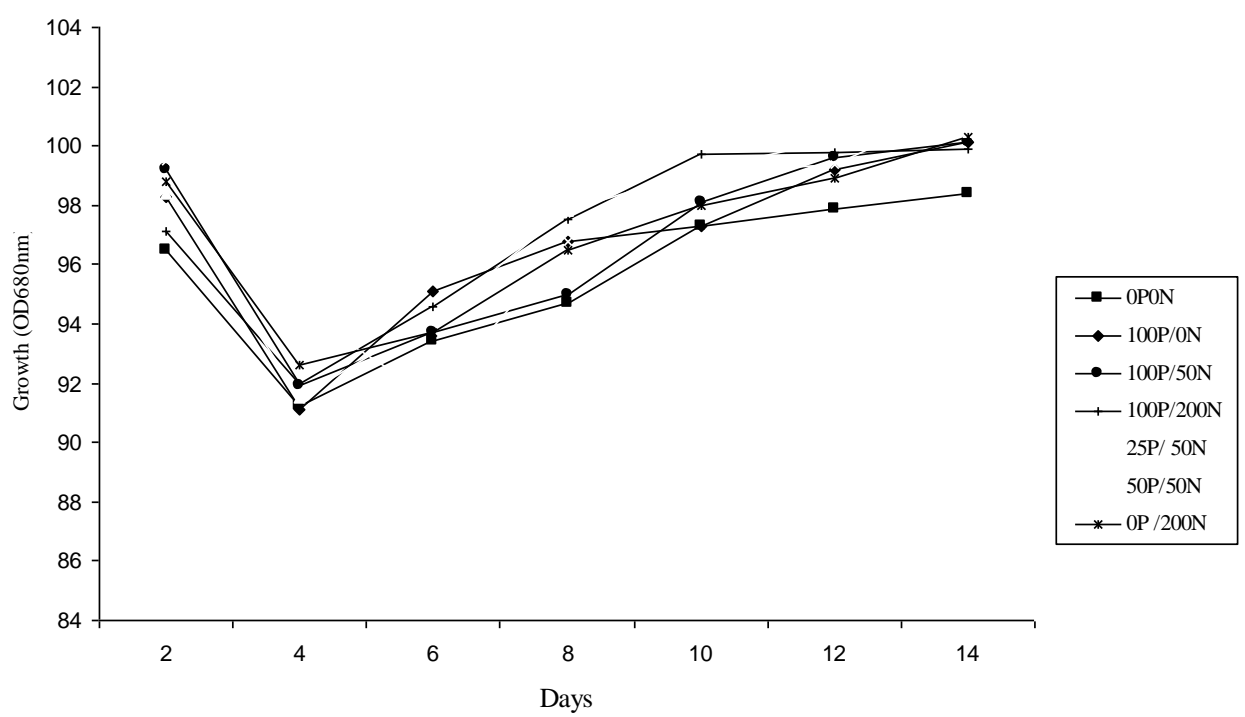

Fig. 5: Growth response at "After effluents discharge point" for all combinations.

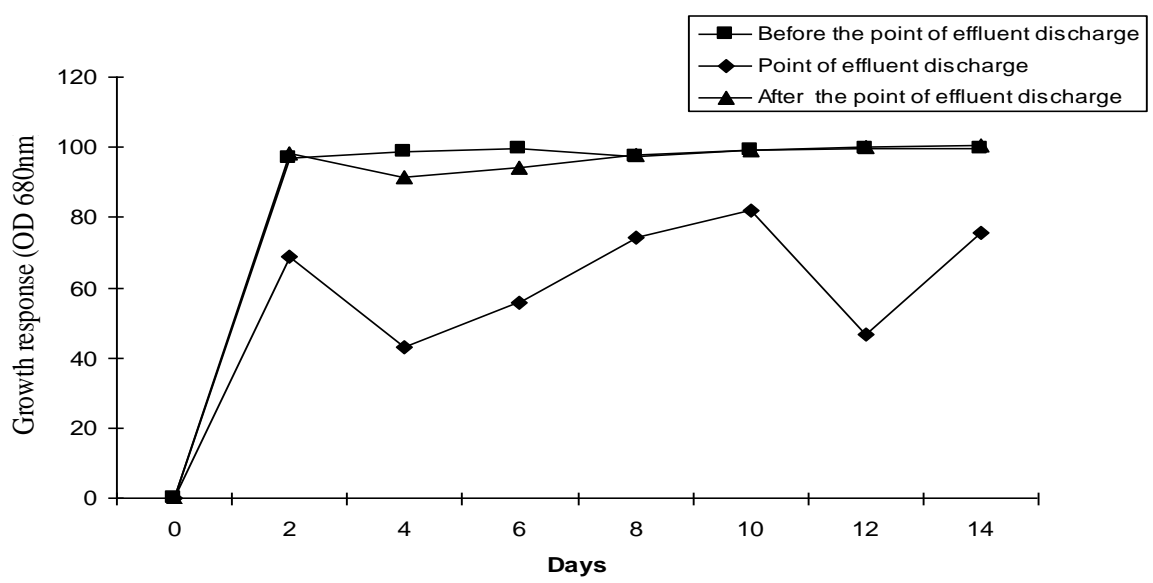

Fig.6a: Indigeneous phytoplankton population growth response to $25^{\mathrm{P}} / 50^{\mathrm{N}}$ nutrient enrichment at the three points. 


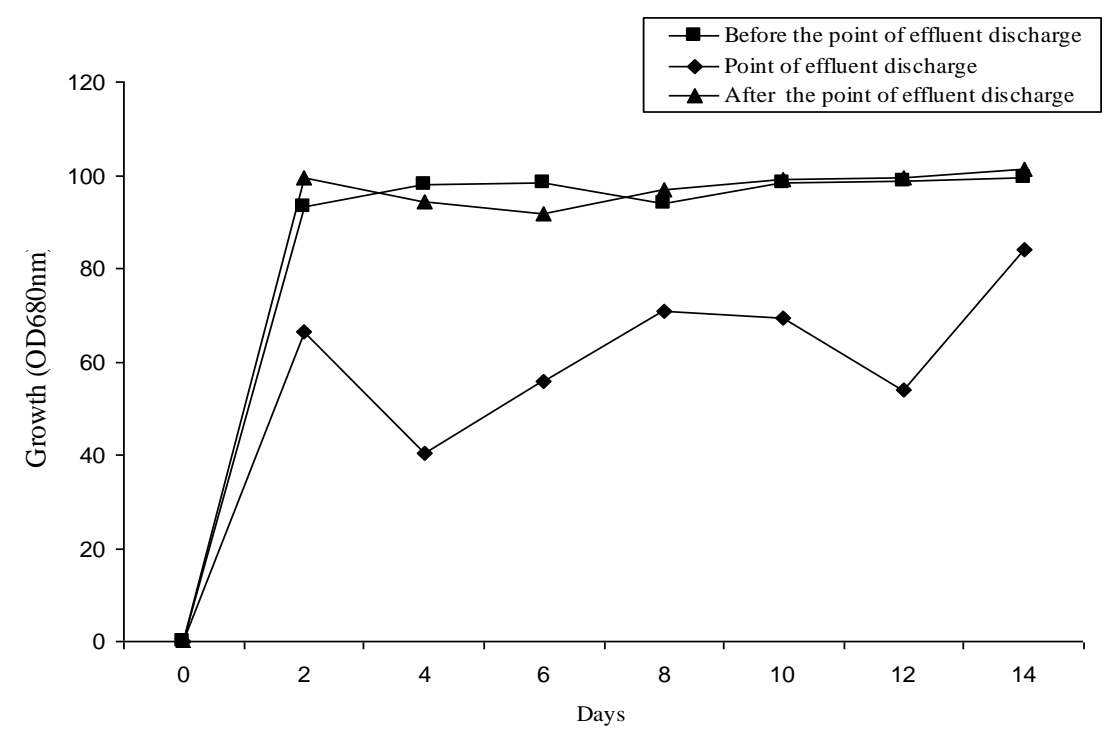

Fig.6b: Phytoplankton growth pattern for $50^{\mathrm{P}} / 50^{\mathrm{N}}$ combinations for all the three points..

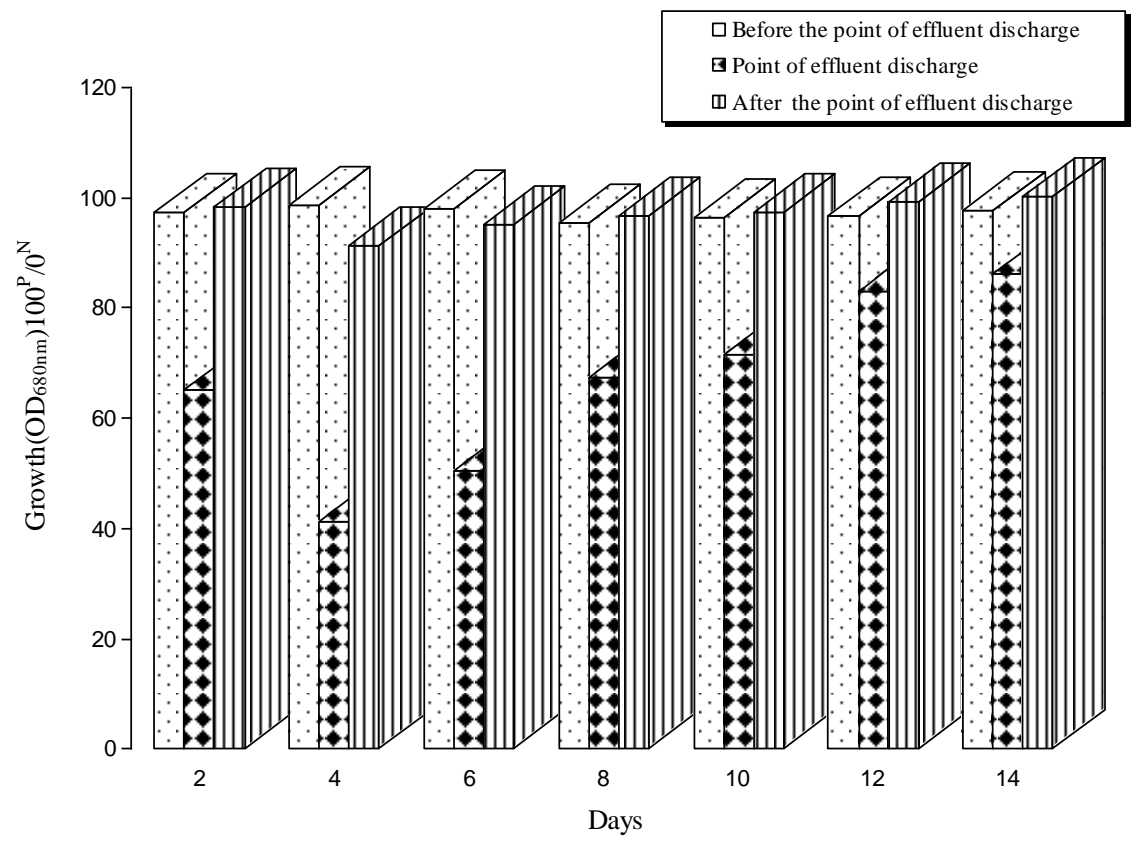

Fig.7: Phytoplankton growth pattern for $100^{\mathrm{P}} / 0^{\mathrm{N}}$ combinations for all the three points 


\section{Discussion}

Results of the physiochemical analysis obtained for this study indicated that the effluents do not maintain the NEQS for $\mathrm{pH}$, Biological oxygen demand and total dissolved solids. The nature of sugar mill effluents poses the most critical danger to the natural ecology of the local water bodies absorbing the wastewaters, with more muted impacts also likely for the fertility of the agricultural land irrigated with the effluents and the populations exposed through using contaminated groundwater. The most notable revelation of the chemical analysis, the presence of an extremely high biological oxygen demand and chemical oxygen demand levels, revealed adversity for the survival of aquatic life through a diminished oxygen supply and the production of toxic hydrogen sulphide.

The resultant foul-smelling septic conditions around the study site would also render the water body a nuisance for local residents and spoil any aesthetic value of the natural environment. These high total suspended solids levels will further endanger aquatic life as it limits light penetration and thereby, photosynthesis by phytoplankton, the primary blocks in the aquatic food chain. High total suspended solids and oil and grease can cause immediate fish kills through clogging fish gills. Agricultural yields may also be impaired through irrigation with effluents high in oil and grease content.The abundance of cyanophytes, chlorophytes and diatoms in sampling sites may probably due to favourable contents of oxidizable organic matter, rich calcium and abundant nutrients such as nitrates and phosphates with less dissolved oxygen. Rai and Kumar (1976) reported that the genus Oscillatoria has been found to be very tolerant to pollution which frequently inhabits the aquatic environment.

The algal growth potential principle is based on Liebig's Law of the minimum which recognizes that the development of a population is essentially regulated by the substance occurring in minimal quantity relative to the requirements of the population. Algal growth potential measurements thus are used frequently to derive information on the required nutrients which are limiting algal growth. This type of measurement is usually designed to examine in detail only a few nutrients which preliminary testing indicates may be limiting or in short supply. The approach is to observe the effects that nutrients have upon the algae. For this study, at the point of effluents the presence of phosphate nutrients probably helped in boosting the growth of organisms. Different views are held on the nutrients limiting the growth of algae and Phosphate-phosphorus has been implicated as the limiting nutrient in aquatic ecosystems (Toerien and Steyn.1973).

For $0^{\mathrm{P}} / 200^{\mathrm{N}}$, the increase in population may be probably because there was a higher concentration of nitrate present which may have boosted the growth of organisms. The combinations, $25^{\mathrm{P}} / 50^{\mathrm{N}}, 50^{\mathrm{P}} / 50^{\mathrm{N}}$ and $0^{\mathrm{P}} / 200^{\mathrm{N}}$ showed a significant differences and the great importance of nitrate over phosphate. This study conformed with the generally accepted view that phosphate limitation is related to its scarcity in most natural fresh water and their underlying geochemical substrate, relative to other chemical constituents of algae (Hutchinson 1967).

This work also in line that phosphate and nitrate are the most important in limiting primary 
productivity and algal growth (Hutchinson, 1967, Schindler, 1977, Toerien et.al., 1975). Some algal growth potential studies have shown correlations between orthophosphate and algal growth (Wang et al.,1972), while correlations also are likely for different nutrients in other aquatic environments. This study supported Kadiri and Azomani (1993) who stated that response to nutrients enrichment by different phytoplankton divisions is somewhat dependent on the background level of the nutrient(s) in question i e limiting nutrient(s) as well as the nutrients combination.

\section{Acknowledgements}

The authors are grateful to department of Botany for providing logistics and Late $\mathrm{Mr}$ Emubaiye for his technical support.

\section{References}

Adesalu T. A., Abiola T. O., \& Bofia, T. O. (2008). Studies on the epiphytic algae associated with two floating aquatic macrophytes in a sluggish non-tidal polluted creek in Lagos, Nigeria. Asian Journal of Scientific Research 1(4), 363-373. http://dx.doi.org/10.3923/ajsr.2008.363.373

Adesalu, T. A. (2007). Phytoplankton dynamics in relation to water quality indices in Lekki lagoon, Lagos. Ph.D thesis, University of Lagos, 267.

Alam, J. B., Islam, M. R., Muyen, Z., Mamun, M., \& Islam, S. (2007). Water quality parameters along rivers. International Journal of Environmental Science and Technology, 4(1), 159- 167. http://dx.doi.org/10.1007/BF03325974

Amadi A. A. (1990). A comparative Ecology of Estuaries in Nigeria. Hydrobiologia, 208, 27-28. http://dx.doi.org/10.1007/BF00008440

American Public Health Association. (1998). Standard methods for the examination of water and waste water, $20^{\text {th }}$ ed. American Public Health Association Incorporated, New York. 1270 pp.

Atkins, P. W. (1991). Physical chemistry (4th ed.) Oxford University press, London, 652pp.

Birge, W. J., Jeffrey, A. B., Terry, M. S., \& Westerman, A. G. (1989). A comparative ecological and toxicological invesigation of a secondary wastewater treatment plant effluentss and its receiving stream. Environmental toxicology and chemistry, 8(5), 437-450. http://dx.doi.org/10.1002/etc.5620080510

Chand, S., \& Dara, S. S. (1997). A Textbook of Environmental Chemistry and Pollution Control. New Delhi, India .

Dublin-Green, C. O., \& Tobor, J. G. (1992). Marine resources and activities in Nigeria. Nigeria Institute of Oceanography and Marine Research Technical Paper, No. 84, 25.

Gerhold, R. M. (1976). Algal nutritional bioassay of Lake Wylie, North Carolina. In: Biostimulation and Nutrient Assessment (edited by: E J. Middlebrooks, D H. Falkenborg and T E. Maloney), Utah State University, Utah, 175-220. 
Greene, J. C., Miller, W. E., Shiroyama, T., \& Maloney, T. E. (1975). Utilization of algal assays to assess the effects of municipal, industrial and agricultural wastewater ffluentss upon phytoplankton production in the Snake River system. Water, Air and Soil Pollution, 4, 415-434. http://dx.doi.org/10.1007/BF00280726

Greene, J. C., Miller, W. E., Shiroyama, T., Soltero, R. A., \& Putnam, K. (1978). Use of laboratory cultures of Selenastrum, Anabaena and the indigenous isolate Sphaerocystis to predict effects of nutrient and zinc interactions upon phytoplankton growth in Long Lake, Washington. Mitt. Int. Verein. Limnol, 21, 372-384.

Greene, J. C., Soltero, R. A., Miller, W. E., Gasperino, A. F., \& Shiroyama, T. (1976). The relationship of laboratory algal assays to measurements of indigenous phytoplankton in Long Lake, Washington. In E. J. Middlebrooks, D. H. Falkenborg \& T.E. Maloney (Eds.), Biostimulation and Nutrient Assessment. Utah State University, Utah, 93-126.

Hutchinson, G. E. (1967). A treatise on Limnology, Vol. II. John Wiley and Sons Inc. New York, 1115.

Ibe, A. C. (1988) .Coastline erosion in Nigeria.University Press Ibadan, 217.

Javed, M., \& Hayat, S. (2002). Heavy metal toxicity of River Ravi aquatic ecosystem. Pakistan Journal of Agricultural Science, 36, 1-9.

Kadiri, M. O., \& Azomani, I. L. (1993). Nutrient enrichment bioassay of a river receiving brewery effluents: A study with indigeneous phytoplankton population. Nigerian Journal of Applied Science, 11, 53-65.

Miller, W. E., \& Maloney, T. E. (1971). Effects of secondary and tertiary wastewater effluentss on algal growth in a lake-river system. Water Pollution Control Federation. Journal, 43, 2361-2365.

Miller, W. E., Maloney, T. E., \& Greene, I. C. (1974). Algal productivity in 49 lake waters as determined by algal assays. Water Resources, 8, 667-679.

Nandan, S. N., \& Patel, R. J. (1986). Assessment of water qualities of Vishwamitri river by algal analysis. Indian J. Environ. Hlth., 29, 160-161.

Nwankwo, D. I., \& Akinsoji, A. (1992). Epiphyte community of water hyacinth, Eichhornia crassipes (MART) Solms in coastal waters of South Western Nigeria. Archiv fur Hydrobiologie, 124(4), 501-511.

Olaniyan, C. I. O. (1975). An introduction to West African Ecology. Heinemann Education Books Ltd., London. 170.

Payne, A. G. (1976). Application of the algal assay procedure in biostimulation and toxicity testing. In E. J. Middlebrooks, D. H. Falkenborg, \& T. E. Maloney (Eds.), Bio stimulation and Nutrient Assessment. Utah State University, Utah, 3-28.

Philips, R. C. (1989). Water quality, sediments, and the macroinvertebrate community of residential canal estates in South-East queensland, Australia: a multivariate analysis. Water 
Res. 23, 1087-1089. http://dx.doi.org/10.1016/0043-1354(89)90152-8

Prasad, B.N \& Manjula, S. (1980). Ecological study of bluegreen algae in the river Gomti, India. Indian Journal of Environmental Health, 22, 151-168.

Rai, L. C., \& Kumar, H. D. (1976). Systematic and ecological studies on algae of some habitats polluted with fertilizer factory effluents. Nova Hedwigia, 27, 805-813.

Sala, O. E., Chapin, F. S., Armesto, J. J., Berlow, E., Bloomfield, J., Dirzo, R., ... Wall, D. H. (2000). Global biodiversity scenarios for the year 2100. Science, 287, 1770-1774. http://dx.doi.org/10.1126/science.287.5459.1770

Toerien, D. F., \& Steyn, D. J. (1973). Application of algal bioassays in eutrophication analysis. South African Journal of Science, 69, 79-82.

Toerien, D. F., Steyn, D. J., \& Kohlmeyers, S. I. (1975). The nitrogen yield coefficient of the green alga Selenastrum capricornum Printz. South African Journal of Science, 71, 218-219.

Wang, W. C., Sullivan, W. T., \& Evans, R. L. (1972). A technique for evaluating algal growth potential in Illinois surface water: Illinois State Water Survey Report Investigation, 16pp.

Whitford, L. A., \& Schumacher, G. J. (1973). A Manual of Fresh-water Algae. Sparks Press, Raleigh, N. C. 324 pp.

Wimpenny, R. S. (1966). The Plankton of the Sea. Faber and Faber Limited, London. 426pp.

Yakubu, A. F., Sikoki, F. D., Abowei, J. F. N., \& Hart, S. A. (2000). A comparative study of phytoplankton communities of some rivers, creeks, and burrow pits in Niger delta areas. Journal of Applied Sciences and Environmental Management, 4, 41-46. 